\title{
Effect of Pyruvate Kinase Deficiency on L-Lysine Productivities of Mutants with Feedback-resistant Aspartokinases
}

\author{
Isamu Shiı, Atsushi YoкотA and Shin-ichi Sugimoto \\ Central Research Laboratories, Ajinomoto Co., Inc., \\ Kawasaki-ku, Kawasaki, Kanagawa 210, Japan
}

Received April 7, 1987

\begin{abstract}
The cultural conditions were investigated for a Brevibacterium flavum mutant, No. 2-190, with a low level of citrate synthase (CS) and with feedback-resistant phosphoenoipyruvate (PEP) carboxylase and aspartokinase (AK). The productivity was increased from 28 to $38 \mathrm{~g} / 1$ (as the $\mathrm{HCl}$ salt) with a medium containing $10 \%$ glucose. From this strain, pyruvate kinase (PK)-defective mutants were derived and selected as to the inability to grow on ribose. Among them, strain KL-18 showed higher lysine productivity than the parent under all cultural conditions tested, and produced $43 \mathrm{~g} / \mathrm{l}$ of lysine, at maximum. A lysine-producing mutant, No. 536-4, with a feedbackresistant AK was derived from PK-defective strain KH-21 which had low CS activity and a feedback-resistant PEP carboxylase. The mutant was isolated by a new selection method, that is, on the basis of resistance to $\alpha$-amino- $\beta$-hydroxyvaleric acid, a threonine analogue plus lysine. In this strain, HD had been altered so as to become feedback-resistant at the same time, resulting in the byproduction of threonine and isoleucine. The total amount of these aspartate family amino acids was higher on molar basis than that of lysine produced by strain No. 2-190.
\end{abstract}

The following three types of lysineproducing mutants of Brevibacterium flavum have been reported ${ }^{1)}$ : mutants with aspartokinases (AK) resistant to feedback inhibition by lysine plus threonine $\left(\mathrm{AK}^{\mathrm{R}}\right)$; threonine- or methionine-sensitive mutants with low homoserine dehydrogenase (HD) activities $\left(\mathrm{HD}^{\mathrm{L}}\right)$; threonine auxotrophs lacking HD or homoserine kinase $(\mathrm{HK})\left(\mathrm{HD}^{-}\right.$or $\left.\mathrm{HK}^{-}\right)$. The lysine productivities of these mutants were further improved by mutational increases in their abilities to supply raw materials for lysine biosynthesis, including aspartate, pyruvate and acetyl-CoA (Fig. 1). The effects of these mutations were not the same among the above three types of lysine producers. ${ }^{2,3)}$ For example, a decrease in the activity of citrate synthase (CS) and resistance of phosphoenolpyruvate (PEP) carboxylase to the feedback inhibition by aspartate, which were considered to increase the intra-cellular levels of acetyl$\mathrm{CoA}$ and aspartate, enhanced the lysine productivities of $\mathrm{AK}^{\mathrm{R}}$ mutants but not those of $\mathrm{HD}^{\mathrm{L}}$ or $\mathrm{HD}^{-}$mutants. On the other hand, pyruvate kinase (PK) deficiency, which was expected to further increase the flux to aspartate, promoted the productivities of $\mathrm{HD}^{\mathrm{L}}$ and $\mathrm{HD}^{-}$mutants. The effects on those of $\mathrm{AK}^{\mathrm{R}}$ mutants still remained to be tested, because there was no selection marker other than resistance to $S$-(2-aminoethyl)-L-cystein (AEC), a lysine analogue, for the isolation of mutants with a $\mathrm{PK}$ defect or $\mathrm{AK}^{\mathrm{R}}$ character, thus making it difficult to obtain mutants having these two characters simultaneously.

In this study, the possibilities of the following two selection methods were investigated: isolation of mutants with $\mathrm{AK}^{\mathrm{R}}$ character by a method other than resistance to AEC; screening of PK-defective strains with a new method

Abbreviations: AEC, $S$-(2-aminoethyl)-L-cysteine; AHV, $\alpha$-amino- $\beta$-hydroxyvaleric acid; NG, $N$-methyl- $N^{\prime}$-nitro$N$-nitrosoguanidine; CTAB, cetyltrimethylammonium bromide; PEP, phosphoenolpyruvate; SMH, soybean-meal hydrolysate; CS, citrate synthase; PK, pyruvate kinase; AK, aspartokinase; HD, homoserine dehydrogenase; AK ${ }^{\mathrm{R}}$, feedback-resistant aspartokinase. 


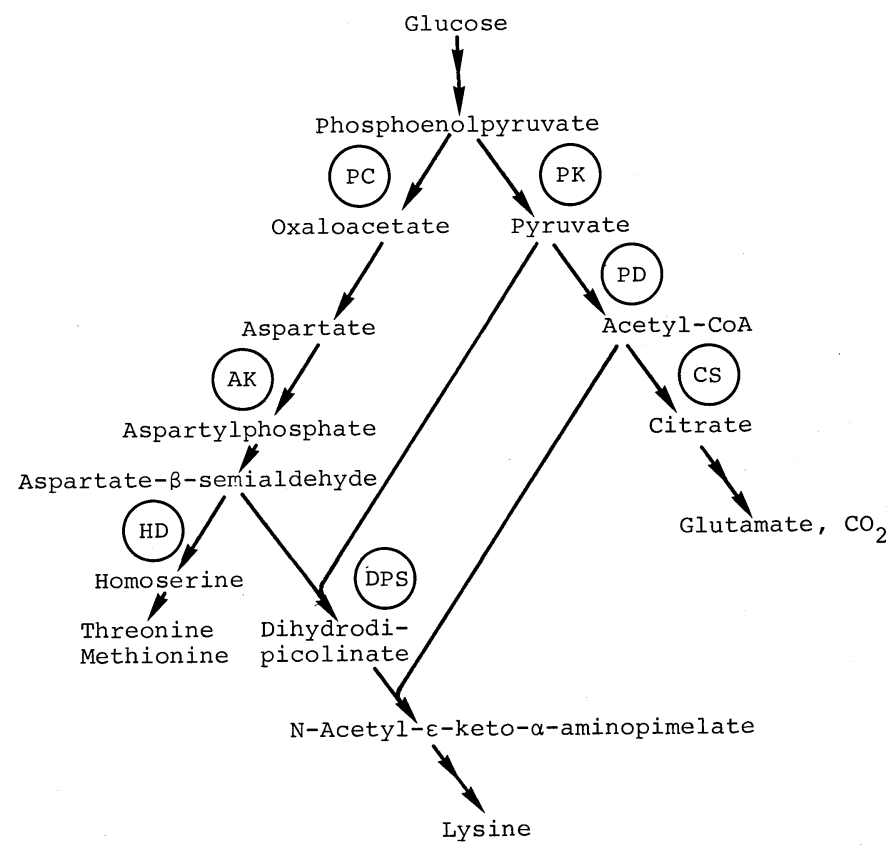

FIG. 1. Enzymes Related to Lysine Biosynthesis in Brevibacterium flavum.

Abbreviations: PK, pyruvate kinase; PC, phosphoenolpyruvate carboxylase; PD, pyruvate dehydrogenase; $\mathrm{CS}$, citrate synthase; AK, aspartokinase; HD, homoserine dehydrogenase; DPS, dihydrodipicolinate synthase.

developed from characteristics of PK-less mutants so far obtained. ${ }^{4)}$ As a result, the enhancing effect of PK deficiency on lysine productivities was also found in $\mathrm{AK}^{\mathrm{R}}$ mutants.

\section{MATERIALS AND METHODS}

Bacterial strains and media. Brevibacterium flavum No. 2247 (ATCC 14067, wild strain) and its lysine-producing mutants, No. $22^{2)}$ with PK and HD defects and No. 2$190^{2,3)}$ with a feedback-resistant AK, both of which were derived from strain 15-8 with a low CS level and a feedback-resistant PEP carboxylase, were used. Medium $\mathrm{T}-2^{5)}$ contained $100 \mathrm{~g}$ of glucose, $30 \mathrm{~g}$ of $\left(\mathrm{NH}_{4}\right)_{2} \mathrm{SO}_{4}, 1.5 \mathrm{~g}$ of $\mathrm{KH}_{2} \mathrm{PO}_{4}, 0.4 \mathrm{~g}$ of $\mathrm{MgSO}_{4} \cdot 7 \mathrm{H}_{2} \mathrm{O}, 10 \mathrm{mg}$ of $\mathrm{FeSO}_{4}$. $7 \mathrm{H}_{2} \mathrm{O}, 8 \mathrm{mg}$ of $\mathrm{MnSO}_{4} \cdot 4 \mathrm{H}_{2} \mathrm{O}, 200 \mu \mathrm{g}$ of $d$-biotin, $300 \mu \mathrm{g}$ of thiamine $\cdot \mathrm{HCl}, 4 \mathrm{ml}$ of Mieki (a mixture of amino acids) and $50 \mathrm{~g}$ of $\mathrm{CaCO}_{3}$ (sterilized separately) in a total volume of 11 , and the $\mathrm{pH}$ was adjusted to 7.2 with $\mathrm{KOH}$. Medium $36^{6)}$ was composed of $100 \mathrm{~g}$ of glucose, $60 \mathrm{~g}$ of $\left(\mathrm{NH}_{4}\right)_{2} \mathrm{SO}_{4}, 1 \mathrm{~g}$ of $\mathrm{KH}_{2} \mathrm{PO}_{4}, 0.4 \mathrm{~g}$ of $\mathrm{MgSO}_{4} \cdot 7 \mathrm{H}_{2} \mathrm{O}$, $10 \mathrm{mg}$ of $\mathrm{FeSO}_{4} \cdot 7 \mathrm{H}_{2} \mathrm{O}, 8 \mathrm{mg}$ of $\mathrm{MnSO}_{4} \cdot 4 \mathrm{H}_{2} \mathrm{O}, 300 \mu \mathrm{g}$ of $d$-biotin, $200 \mu \mathrm{g}$ of thiamine $\cdot \mathrm{HCl}, 35 \mathrm{ml}$ of soybean-meal acid hydrolysate $(\mathrm{SMH}, 32 \mathrm{~g}$ total-N/1), $50 \mathrm{mg}$ of $\mathrm{L}-$ methionine, $50 \mathrm{~g}$ of $\mathrm{CaCO}_{3}$ (sterilized separately) and $\mathrm{NaOH}$, to adjust the $\mathrm{pH} 7.0$, per liter. Medium $7,{ }^{7)}$ Medium 8, ${ }^{7)}$ Medium 10, ${ }^{7)}$ Medium 13, ${ }^{7)}$ Medium $33^{2)}$ and
Medium $41^{4)}$ were reported previously.

Chemicals. $\alpha$-Amino- $\beta$-hydroxyvaleric acid (AHV) and ribose were purchased from Sigma. DL-Aspartate- $\beta$ semialdehyde was prepared by ozonolysis of DLallylglycine by the method of Black and Wright. ${ }^{8)}$ The other reagents were as described previously.

Production of lysine. Method A: A loopful of cells grown on Medium 7 supplemented with $10 \mathrm{~g} / 1$ of monosodium glutamate for $24 \mathrm{hr}$ was inoculated into $3 \mathrm{ml}$ of Medium T2 in a test tube and then cultured at $30^{\circ} \mathrm{C}$ for $72 \mathrm{hr}$. The cultivation temperature was $30^{\circ} \mathrm{C}$ throughout this study. Method B: Two loopfuls of cells obtained as in method A were inoculated into $20 \mathrm{ml}$ of Medium 36 without Lmethionine in a $500-\mathrm{ml}$ shaking flask and then cultured for $72 \mathrm{hr}$. Amino acids produced were detected by thin-layer chromatography using a solvent system of phenol: $\mathrm{H}_{2} \mathrm{O}=7: 3$. Lysine in the culture broth was assayed as described previously. ${ }^{9)}$ Isoleucine was determined microbiologically using Leuconostoc mesenteroides ATCC 8042.

Enzyme preparation. As a culture medium for cell preparation, Medium 33 supplemented with $5 \mathrm{~g} / \mathrm{l}$ of yeast extract was used for AK assay, while Medium T-2 was employed for HD measurement. The cells were cultured in $500-\mathrm{ml}$ shaking flasks containing $20 \mathrm{ml}$ of the above media for $40 \mathrm{hr}$ and washed twice with $0.2 \% \mathrm{KCl}$ solution. The 
crude extract for HD assay was prepared by sonic disruption of the cells in $0.1 \mathrm{M}$ potassium phosphate buffer, $\mathrm{pH}$ 7.0 , containing $0.5 \mathrm{M} \mathrm{KCl}$, followed by centrifugation at $30,000 \times g, 0^{\circ} \mathrm{C}$, for $30 \mathrm{~min}$. The supernatant solution was passed through a column of Sephadex G-50 with the same buffer to eliminate low molecular weight contaminants. The crude extract for AK measurement was prepared by sonic disintegration in $0.05 \mathrm{M}$ potassium phosphate buffer, $\mathrm{pH} 7.0$, containing $0.01 \mathrm{M} \mathrm{MgSO}_{4}$ and $0.8 \mathrm{M}\left(\mathrm{NH}_{4}\right)_{2} \mathrm{SO}_{4}$, followed by centrifugation. To the extract, five volumes of a saturated $(\mathrm{NH})_{2} \mathrm{SO}_{4}$ solution was added. The precipitate that had formed at $0^{\circ} \mathrm{C}$ after $30 \mathrm{~min}$ was collected by centrifugation at $14000 \times g, 0^{\circ} \mathrm{C}$, for $20 \mathrm{~min}$. PK was assayed with a crude extract ${ }^{2)}$ or CTAB-treated cells, ${ }^{4}$ ) both prepared as described previously from cells grown in $50 \mathrm{ml}$ of Medium 8 in $500-\mathrm{ml}$ shaking flasks for $24 \mathrm{hr}$.

Enzyme assay. HD was assayed as reported in the previous paper ${ }^{10)}$ in a reaction mixture containing $0.2 \mathrm{~mm}$ aspartate- $\beta$-semialdehyde (as the L-from). The methods for the determination of $\mathrm{AK}^{11)}$ and $\mathrm{PK}^{12)}$ with crude extracts were described previously. The PK activities of CTAB-treated cells were assayed as mentioned in the preceding paper. ${ }^{4)}$

Isolation of homoserine dehydrogenase revertants. PKand HD-defective strain No. 22 cultured in $4 \mathrm{ml}$ of Medium 7 supplemented with $10 \mathrm{~g} / 1$ of monosodium glutamate, but without agar for $15 \mathrm{hr}$, was harvested, washed twice with $0.1 \mathrm{~m}$ sodium phosphate buffer, $\mathrm{pH} 7.0$, resuspended in the same buffer, and then treated with $300 \mu \mathrm{g} / \mathrm{ml}$ of $N$-methyl- $N^{\prime}$-nitro- $N$-nitrosoguanidine (NG) at $30^{\circ} \mathrm{C}$ for $15 \mathrm{~min}$. The treated cells were washed and then spread on agar plates of Medium 10 supplemented with $300 \mu \mathrm{g} / \mathrm{l}$ of $d$-biotin and $500 \mathrm{mg} / \mathrm{l}$ of L-methionine at the inoculum size of $10^{4}$ to $10^{6}$ cells per plate (diameter, $9 \mathrm{~cm}$ ). After cultivation for 4 days, colonies that had appeared on the plates were picked up and then their growth was further confirmed on the agar plates described above. From the strains, mutants unable to produce lysine were selected by method A (with the exception that Medium 36 was used). The above selection methods made it possible to eliminate most of the mutants with partially reverted HDs, which were sensitive to methionine and produced lysine. Then, the HD activities of these selected strains were measured and strain $\mathrm{KH}-21$, which showed HD activity as high as that of strain No. 2247, was obtained.

Derivation of mutants resistant to AHV or AHV plus lysine. Washed cells of strain $\mathrm{KH}-21$ were prepared by the same method as described above except that Medium 13 supplemented with $300 \mu \mathrm{g} / 1$ of $d$-biotin was used. They were then treated with $150 \mu \mathrm{g} / \mathrm{ml}$ of $\mathrm{NG}$ at $30^{\circ} \mathrm{C}$ for $15 \mathrm{~min}$, and then spread on agar plates of the same medium supplemented with AHV (5 to $20 \mathrm{~g} / \mathrm{l}$ ) or AHV plus lysine (each $5 \mathrm{~g} / \mathrm{l}$ ) at the inoculum size of 5 to $8 \times 10^{7}$ cells per plate (diameter, $9 \mathrm{~cm}$ ). Colonies that appeared during cultivation for 8 days were picked up.

Derivation of pyruvate kinase-defective mutants. The method used was basically the same as that described in the preceding paper. ${ }^{4)}$ Cells of strain No. 2-190 were treated with $\mathrm{NG}$ in the same way as for strain $\mathrm{KH}-21$, except that the NG concentration was $400 \mu \mathrm{g} / \mathrm{ml}$, and then spread on Medium 7 plates supplemented with $10 \mathrm{~g} / \mathrm{l}$ of monosodium glutamate. Colonies that appeared on 3-day cultivation were replicated onto agar plates of Medium 41 supplemented with $0.1 \%$ of Casamino acids, and the same medium containing ribose instead of glucose. After cultivation for $24 \mathrm{hr}$, colonies which grew on the former but not on the latter were picked up. Among them, strains which showed pyruvate auxotrophy on the latter ribose plate were assayed for their PK activities, using CTAB-treated cells. Those without detectable PK activities were selected as PK-defective mutants, and the absence of activities was further confirmed using their crude extracts.

\section{RESULTS}

Derivation of mutants with feedback-resistant aspartokinases from a pyruvate kinasedefective strain, $\mathrm{KH}-21$

Mutants with feedback-resistant AKs are selected on the basis of their resistance to AEC, a lysine analogue plus threonine. ${ }^{1)}$ However, it was impossible to select such mutants from strain KH-21 by means of AEC plus threonine-resistance, because strain No. 22, the parent of strain $\mathrm{KH}-21$, was derived from strain No. 1-231, ${ }^{3)}$ which is resistant to AEC plus threonine. Therefore, an attempt was made to select them as to the resistance to $\mathrm{AHV}$, a threonine analogue plus lysine, which was the reverse combination of AEC plus threonine. As reported already with Brevibacterium lactofermentum, ${ }^{13)}$ AEC plus threonine-resistant strain $\mathrm{KH}-21$ was still sensitive to AHV plus lysine. The mutants resistant to AHV plus lysine were cultured by method $\mathrm{A}$ and the amino acids produced were detected by thin-layer chromatography. As a control experiment, selection of AHV-resistant mutants, which was commonly used as a method for breeding threonine producers, was also performed, and the mutants were cultured under the same conditions. As shown in Table 
TAble I. Derivation of $\alpha$-Amino- $\beta$-hydroxyvaleric ACID (AHV) OR AHV PLUS LySINE RESISTANT Mutants From Strain KH-21

The derivation conditions were given under MATERIALS AND METHODS. Resistant strains were cultured by method A, except that the $\left(\mathrm{NH}_{4}\right)_{2} \mathrm{SO}_{4}$ concentration in the production medium was $20 \mathrm{~g} / \mathrm{l}$. Amino acids produced in the culture broth were detected by thin-layer chromatography.

\begin{tabular}{lccc}
\hline $\begin{array}{l}\text { Selection by } \\
\text { resistance to }\end{array}$ & $\begin{array}{c}\text { Number of } \\
\text { mutants } \\
\text { tested }\end{array}$ & $\begin{array}{c}\text { Number of } \\
\text { threonine } \\
\text { producers }\end{array}$ & $\begin{array}{c}\text { Number of } \\
\text { lysine } \\
\text { producers }\end{array}$ \\
\hline $\begin{array}{c}\mathrm{AHV}^{a}+\text { lysine } \\
\text { at each } 5 \mathrm{~g} / \mathrm{l}\end{array}$ & 270 & 20 & $2^{b}$ \\
$\begin{array}{l}\mathrm{AHV} \text { at } 5 \text { to } \\
20 \mathrm{~g} / \mathrm{l}\end{array}$ & 2600 & 344 & 0
\end{tabular}

a $\alpha$-Amino- $\beta$-hydroxyvaleric acid.

$b$ Strain Nos. 422-1 and 536-4.
I, it was found that whereas the frequency of the appearance of threonine producers was almost the same between the two phenotypes, lysine producers were specifically found at a frequency of 2 out of 260 strains of AHV plus lysine-resistant mutants, but there were none among 2600 strains of AHV-resistant mutants. The two strains, Nos. 422-1 and 536-4, produced 17 and $14 \mathrm{~g} / 1$ of lysine, respectively, with the additional production of threonine, less than $4 \mathrm{~g} / \mathrm{l}$, after $72 \mathrm{hr}$ cultivation in $20 \mathrm{ml}$ of Medium T-2 containing $20 \mathrm{~g} / \mathrm{l}$ of $\left(\mathrm{NH}_{4}\right)_{2} \mathrm{SO}_{4}$ in $500-\mathrm{ml}$ shaking flasks.

In order to clarify the mechanism of lysine production in strain Nos. 422-1 and 536-4, their AK and HD activities were assayed. As shown in Table II, both AKs and HDs of the strains became resistant to feedback inhibition by threonine plus lysine and by threonine,

Table II. Enzymatic Properties of Mutants Resistant to $\alpha$-AMINO- $\beta$-HYDROXYVALERIC ACID PLUS LYSINE

Enzyme activities were measured as described under Materials AND METHODS.

\begin{tabular}{|c|c|c|c|c|}
\hline \multirow{2}{*}{ Enzymatic properties } & \multicolumn{4}{|c|}{ Strain } \\
\hline & 2247 & KH-21 & $536-4$ & $422-1$ \\
\hline \multicolumn{5}{|l|}{ Aspartokinase } \\
\hline Specific activity ${ }^{a}$ & 13.1 & 11.5 & 10.4 & 7.6 \\
\hline \multicolumn{5}{|l|}{$\begin{array}{l}\text { Relative activity in the } \\
\text { presence of effectors }\end{array}$} \\
\hline None & $100 \%$ & 100 & 100 & 100 \\
\hline Lysine, $1 \mathrm{~mm}$ & 82 & 71 & 84 & 76 \\
\hline Threonine, $1 \mathrm{~mm}$ & 105 & 57 & 103 & 309 \\
\hline Lysine + Threonine, each $1 \mathrm{~mm}$ & 4 & 9 & 96 & 277 \\
\hline \multicolumn{5}{|l|}{ Homoserine dehydrogenase } \\
\hline Specific activity $^{a}$ & 192 & 229 & 238 & 116 \\
\hline \multicolumn{5}{|l|}{$\begin{array}{l}\text { Relative activity in the } \\
\text { presence of threonine at }\end{array}$} \\
\hline $0 \mathrm{~mm}$ & $100 \%$ & 100 & 100 & 100 \\
\hline 0.05 & $-b$ & 67 & 93 & 100 \\
\hline 0.1 & - & 15 & 93 & 105 \\
\hline 0.5 & - & 3 & 91 & 94 \\
\hline 1.0 & 4 & 3 & 88 & 101 \\
\hline 5.0 & - & - & - & 66 \\
\hline 10.0 & - & - & 82 & 35 \\
\hline 20.0 & - & - & 71 & 11 \\
\hline 40.0 & - & - & 84 & - \\
\hline 80.0 & - & - & 51 & - \\
\hline
\end{tabular}

a $\mathrm{nmol} / \mathrm{min} / \mathrm{mg}$ protein.

$b \quad$ Not determined. 
Table III. Effects of the Soybean-meal Hydrolysate and $\left(\mathrm{NH}_{4}\right)_{2} \mathrm{SO}_{4}$ Concentrations on Lysine Production in Strain 536-4

Each strain was cultured by method B described under MATERIALS AND METHODS for $72 \mathrm{hr}$, except that the culture medium contained the indicated concentrations of soybean-meal hydrolysate $(\mathrm{SMH})$ and $\left(\mathrm{NH}_{4}\right)_{2} \mathrm{SO}_{4}$. The underlines indicate the concentration of each component in the basal medium, i.e., Medium 36 without $\mathrm{L}-$ methionine.

\begin{tabular}{|c|c|c|c|c|c|c|}
\hline \multirow{2}{*}{ Strain } & \multicolumn{2}{|c|}{ Culture conditions } & \multirow{2}{*}{$\begin{array}{c}\text { Growth } \\
\left(A_{562}\right)\end{array}$} & \multicolumn{3}{|c|}{ Amino acids production } \\
\hline & $\begin{array}{l}\mathrm{SMH} \\
(\mathrm{ml} / \mathrm{l})\end{array}$ & $\begin{array}{c}\left(\mathrm{NH}_{4}\right)_{2} \mathrm{SO}_{4} \\
(\mathrm{~g} / \mathrm{l})\end{array}$ & & $\begin{array}{l}\text { Lys } \cdot \mathrm{HCl} \\
\quad(\mathrm{g} / \mathrm{l})\end{array}$ & $\begin{array}{l}\text { Ile } \\
(\mathrm{g} / \mathrm{l})\end{array}$ & $\begin{array}{c}\text { Lys } \cdot \mathrm{HCl}+\mathrm{Ile} \\
\text { (as Lys } \cdot \mathrm{HCl}, \mathrm{g} / \mathrm{l} \text { ) }\end{array}$ \\
\hline \multirow[t]{11}{*}{$536-4$} & 25 & 30 & 0.89 & 30.1 & 3.7 & 35.3 \\
\hline & & 40 & 0.94 & 34.2 & 5.4 & 41.7 \\
\hline & & 50 & 0.92 & 32.8 & 5.2 & 40.0 \\
\hline & 30 & 30 & 0.92 & 31.2 & 3.6 & 36.2 \\
\hline & & 40 & 0.93 & 35.4 & 5.2 & 42.6 \\
\hline & & 50 & 0.92 & 33.3 & 5.2 & 40.5 \\
\hline & & 60 & 0.82 & 27.3 & 4.4 & 33.3 \\
\hline & 35 & 30 & 0.94 & 32.0 & 3.7 & 37.1 \\
\hline & & 40 & 0.92 & 35.2 & 5.2 & 42.4 \\
\hline & & 50 & 0.95 & 34.0 & 5.4 & 41.5 \\
\hline & & $\underline{60}$. & 0.87 & 32.3 & 4.8 & 39.0 \\
\hline $2-190$ & 45 & 100 & 0.99 & 38.0 & 0 & 38.0 \\
\hline
\end{tabular}

respectively. Thus, it was confirmed that the lysine production by these strains was due to the resistance of AKs to concerted feedback inhibition. It was also observed that the spcific activity of AK in strain No. 422-1 was decreased to a half of that of wild type strain No. 2247, but was increased by $1 \mathrm{~mm}$ each of threonine and lysine to a level comparable to that of strain No. 2247.

\section{Lysine production by strain No.536-4}

To determine whether or not a PK deficiency was effective for the improvement of the lysine productivities of $\mathrm{AK}^{\mathrm{R}}$ mutants, the cultural conditions for lysine production by strain No. 536-4 with a feedback-resistant AK and a PK defect were examined using Medium 36 without L-methionine as the standard medium, and the productivities were compared with those of $\mathrm{AK}^{\mathrm{R}}$ lysine producer No. 2-190, which had a normal PK and was derived directly from strain No. $15-8,{ }^{2)}$ the original strain of mutant No. 536-4. Strain No. 422-1 was not employed because of its poor growth in the standard medium. As shown in Table III, strain No. 536-4 produced $35.4 \mathrm{~g} / 1$ of lysine, at maximum, in the medium containing lower concentrations of SMH $(30 \mathrm{ml} / \mathrm{l})$ and $\left(\mathrm{NH}_{4}\right)_{2} \mathrm{SO}_{4}(40 \mathrm{~g} / \mathrm{l})$ than those in the standard medium (SMH $\left.35 \mathrm{ml} / 1,\left(\mathrm{NH}_{4}\right)_{2} \mathrm{SO}_{4} 60 \mathrm{~g} / \mathrm{l}\right)$. This productivity was not more than that of strain No. 2-190, $38 \mathrm{~g} / \mathrm{l}$, under the optimum conditions ( $\mathrm{SMH} 45 \mathrm{ml} / 1,\left(\mathrm{NH}_{4}\right)_{2} \mathrm{SO}_{4} 100 \mathrm{~g} / \mathrm{l}$, see Table IV). However, as mentioned above, No. 536-4 had a feedback-resistant HD, and thus produced $5.2 \mathrm{~g} / \mathrm{l}$ of isoleucine in addition to lysine. Here, we have estimated the total production of lysine and isoleucine as that of lysine, under the assumption that aspartate- $\beta$ semialdehyde, a common intermediate of lysine and isoleucine biosynthesis, was exclusively converted to lysine. As shown in Table III, the estimated lysine productivity of strain No. $536-4$ was $42.6 \mathrm{~g} / \mathrm{l}$ under the optimum conditions, i.e., higher than that of strain No. 2-190. These results suggest that a PK deficiency might be effective for the improvement of the lysine productivities of $\mathrm{AK}^{\mathrm{R}}$ 
Table IV. Derivation of Pyruvate Kinase-defective Mutants from Strain No. 2-190

PK-Defective mutants were derived as described under MATERIALS AND METHODS. The growth response was tested by culturing the parent and mutant strains for $24 \mathrm{hr}$ on Medium 41 supplemented with $0.1 \%$ of Casamino acids, and on the same medium containing ribose or ribose plus sodium pyruvate $(5 \mathrm{~g} / \mathrm{l})$ instead of glucose. PK activities were assayed using CTAB-treated cells and expressed relative to that of the parent strain. Lysine production was conducted by method B given under MATERIALS AND METHODS, except that the culture medium contained $70 \mathrm{~g} / \mathrm{l}$ of $\left(\mathrm{NH}_{4}\right)_{2} \mathrm{SO}_{4}$.

\begin{tabular}{|c|c|c|c|c|c|}
\hline \multirow{2}{*}{ Strain } & \multicolumn{3}{|c|}{ Growth } & \multirow{2}{*}{$\begin{array}{c}\text { Pyruvate kinase } \\
\text { activity } \\
(\%)\end{array}$} & \multirow{2}{*}{$\begin{array}{l}\text { Lys } \cdot \mathrm{HCl} \\
\text { production } \\
(\mathrm{g} / \mathrm{l})\end{array}$} \\
\hline & Glucose & Ribose & $\begin{array}{l}\text { Ribose }+ \\
\text { pyruvate }\end{array}$ & & \\
\hline $2-190$ & +++ & +++ & ++ & 100 & 28.9 \\
\hline 18 & +++ & - & + & 0 & 37.8 \\
\hline 21 & ++ & \pm & ++ & 128 & $\underline{-}^{a}$ \\
\hline 22 & +++ & - & + & 0 & 35.9 \\
\hline 48 & +++ & \pm & ++ & 119 & - \\
\hline 98 & +++ & \pm & ++ & 103 & - \\
\hline 105 & +++ & - & + & 122 & - \\
\hline 117 & ++ & - & + & 106 & - \\
\hline 128 & +++ & \pm & ++ & 100 & - \\
\hline 166 & ++ & \pm & ++ & 32 & 15.1 \\
\hline 168 & ++ & - & + & 133 & - \\
\hline 174 & +++ & \pm & ++ & 96 & - \\
\hline 202 & ++ & - & + & 5 & 31.5 \\
\hline 251 & ++ & - & + & 100 & - \\
\hline 275 & ++ & \pm & + & 169 & - \\
\hline
\end{tabular}

a Not determined.

type mutants. However, in order to confirm more clearly the effect of a PK defect on lysine productivity, it seemed necessary to derive $\mathrm{AK}^{\mathrm{R}}$ type lysine producers with a normal HD but a PK defect.

\section{Derivation of pyruvate kinase-defective mutants} from strain No. 2-190 with feedbackresistant aspartokinase

For the above purpose, PK-defective mutants were derived from the $\mathrm{AK}^{\mathrm{R}}$ type lysine producer, No. 2-190, and selected by a new screening method, ${ }^{4)}$ i.e., the inability to grow on ribose in the absence of pyruvate. From among 20000 NG-treated cells, 14 strains which showed no or only poor growth and pyruvate auxotrophy on ribose were selected, and their PK activities were assayed using CTAB-treated cells. Three PK-defective mutants (KL-18, 22 and 202) and one mutant (KL-166) with low PK activity were found and examined as to their lysine productivities. As shown in Table IV, all the three defective mutants showed higher productivity than that of the parent strain, $28.9 \mathrm{~g} / \mathrm{l}$. The two best strains, KL-18 and KL-22, had low but detectable levels of PK activity, 2 to $4 \%$ of that of the parent strain, No. 2-190, when assayed using crude extracts, as shown in Table V. Furthermore, no significant changes were observed both in the specific activities of $\mathrm{AK}$ and HD and in the feedback inhibition of $\mathrm{AK}$ between strain KL-18 and its parent strain, No. 2-190. These results indicate that the improvement of lysine productivity was due to, the PK deficiency. It was also found that the specific AK activity of strain No. 2-190 had been decreased to one tenth of that of the original wild strain, No. 2247.

\section{Lysine production by strain $K L-18$}

Table VI shows the effects of the SMH and 
Table V. Enzymatic Properties of Strains KL-18 and KL-22

The experimental conditions were given under MATERIALS AND METHODS.

\begin{tabular}{|c|c|c|c|c|}
\hline \multirow{2}{*}{ Strain } & \multirow{2}{*}{$\begin{array}{l}\text { Pyruvate } \\
\text { kinase } \\
\text { activity }^{a}\end{array}$} & \multicolumn{2}{|c|}{ Aspartokinase } & \multirow{2}{*}{$\begin{array}{l}\text { Homoserine } \\
\text { dehydrogenase } \\
\text { activity }^{a}\end{array}$} \\
\hline & & Activity $^{a}$ & Inhibition $^{b}$ & \\
\hline 2247 (wild) & 1243 & 13.1 & 96.0 & 192 \\
\hline 2-190 (parent) & 1312 & 1.3 & 29.7 & 175 \\
\hline KL-18 & 31 & 1.4 & 23.1 & 205 \\
\hline KL-22 & 56 & $-^{c}$ & - & - \\
\hline
\end{tabular}

a $\mathrm{nmol} / \mathrm{min} / \mathrm{mg}$ protein.

${ }^{b} \%$ Inhibition by $1 \mathrm{~mm}$ L-lysine plus L-threonine.

c Not tested.

Table VI. Effects of the Soybean-meal Hydrolysate and $\left(\mathrm{NH}_{4}\right)_{2} \mathrm{SO}_{4}$ Concentrations on the Lysine Production in Strains 2-190 and KL-18

Each strain was cultured for $72 \mathrm{hr}$ as in Table III except that the culture medium contained the indicated concentrations of soybean-meal hydrolysate $(\mathrm{SMH})$ and $\left(\mathrm{NH}_{4}\right)_{2} \mathrm{SO}_{4}$. The underlines show the concentrations in Table III.

\begin{tabular}{|c|c|c|c|c|c|}
\hline \multicolumn{2}{|c|}{ Culture conditions } & \multicolumn{2}{|c|}{$2-190$} & \multicolumn{2}{|c|}{ KL-18 } \\
\hline $\begin{array}{l}\text { SMH } \\
(\mathrm{ml} / \mathrm{l})\end{array}$ & $\begin{array}{c}\left(\mathrm{NH}_{4}\right)_{2} \mathrm{SO}_{4} \\
(\mathrm{~g} / \mathrm{l})\end{array}$ & $\begin{array}{c}\text { Growth } \\
\left(A_{562}\right)\end{array}$ & $\begin{array}{l}\text { Lysine } \cdot \mathrm{HCl} \\
(\mathrm{g} / \mathrm{l})\end{array}$ & $\begin{array}{c}\text { Growth } \\
\left(A_{562}\right)\end{array}$ & $\begin{array}{l}\text { Lysine } \cdot \mathrm{HCl} \\
(\mathrm{g} / \mathrm{l})\end{array}$ \\
\hline \multirow[t]{4}{*}{35} & 70 & 1.16 & 25.9 & 1.08 & 35.6 \\
\hline & 80 & 1.06 & 32.0 & 1.08 & 38.2 \\
\hline & 90 & 1.00 & 35.6 & 0.93 & 39.2 \\
\hline & 100 & 0.96 & 37.8 & 0.88 & 39.0 \\
\hline \multirow[t]{5}{*}{40} & 70 & 1.16 & 26.2 & 1.06 & 35.6 \\
\hline & 80 & 1.08 & 31.3 & 1.01 & 38.1 \\
\hline & 90 & 1.02 & 36.1 & 0.92 & 39.2 \\
\hline & 100 & 0.97 & 36.1 & 0.88 & 39.9 \\
\hline & 110 & 0.76 & 24.0 & $-^{a}$ & - \\
\hline \multirow[t]{5}{*}{$\underline{45}$} & 70 & - & - & 1.07 & 37.8 \\
\hline & 80 & - & - & 0.98 & 39.7 \\
\hline & 90 & 1.03 & 35.6 & 0.94 & 40.9 \\
\hline & 100 & 0.99 & 38.0 & 0.88 & 42.7 \\
\hline & $\overline{110}$ & 0.80 & 25.1 & 0.74 & 26.2 \\
\hline \multirow[t]{3}{*}{50} & 90 & 1.02 & 36.6 & 0.98 & 38.3 \\
\hline & 100 & 0.98 & 36.2 & 0.94 & 41.2 \\
\hline & 110 & 0.79 & 25.2 & 0.82 & 33.6 \\
\hline
\end{tabular}

a Not done.

$\left(\mathrm{NH}_{4}\right)_{2} \mathrm{SO}_{4}$ concentrations on the lysine production by strain KL-18. Strain KL-22 was not used because of the decrease in lysine productivity in the later experiments. The maximum amount of lysine produced, 42.7. $\mathrm{g} / \mathrm{l}$, was obtained with $45 \mathrm{ml} / 1$ of SMH and $100 \mathrm{~g} / \mathrm{l}$ of $\left(\mathrm{NH}_{4}\right)_{2} \mathrm{SO}_{4}$. This yield was higher than that of the parent strain, No. $2-190,38 \mathrm{~g} / 1$, at maximum, obtained under the same conditions. Moreover, strain KL-18 showed higher productivity than the parent strain under all the conditions tested. These results confirmed that 
the PK deficiency was effective for the improvement of the lysine productivities of $\mathrm{AK}^{\mathrm{R}}$ mutants.

In strain KL-18, the optimum concentration of $\left(\mathrm{NH}_{4}\right)_{2} \mathrm{SO}_{4}$ for lysine production was markedly different from that in the case of strain No. 536-4. In both strains, higher concentrations of $\left(\mathrm{NH}_{4}\right)_{2} \mathrm{SO}_{4}$ were favorable for lysine production. However, severe growth inhibition occurred under the conditions of excess $\left(\mathrm{NH}_{4}\right)_{2} \mathrm{SO}_{4}$, resulting in decreases in the lysine yields. In strain KL-18, the maximum amount of lysine was obtained when the $\left(\mathrm{NH}_{4}\right)_{2} \mathrm{SO}_{4}$ concentration was high enough to cause slight growth inhibition. Thus, the difference in the optimum $\left(\mathrm{NH}_{4}\right)_{2} \mathrm{SO}_{4}$ concentration for the two strains seemed to be due to the difference in the degree of resistance to $\left(\mathrm{NH}_{4}\right)_{2} \mathrm{SO}_{4}$.

\section{DISCUSSION}

In order to test the effects of a PK deficiency on the lysine productivities of $\mathrm{AK}^{\mathrm{R}}$ type producers, mutants with both feedback-resistant AKs and a PK defect were derived by two new methods.

As reported in the previous paper, ${ }^{6)} \mathrm{PK}$ defective mutants had already acquired resistance to AEC, a lysine analogue plus threonine. Thus, it was impossible to isolate mutants with AKs resistant to feedback inhibition by lysine plus threonine from the above PK-defective strains by means of the conventional selection marker of resistance to AEC plus threonine. Tosaka et al. ${ }^{13)}$ reported that a strain of Brevibacterium lactofermentum resistant to AEC plus threonine was still sensitive to $\mathrm{AHV}$, a threonine analogue plus lysine, and that the AK of the lysine-producing resistant strain thus obtained became insensitive to the feedback inhibition by lysine alone, but no change was seen in the sensitivity to the concerned feedback inhibition by lysine plus threonine. In accordance with these findings, strain $\mathrm{KH}-21$, a mutant of Brevibacterium flavum with a PK defect and AEC plus threonine resistance, was sensitive to AHV plus lysine. However, unlike the results of Tosaka et al., the AKs of the lysine-producing resistant mutants obtained, strain Nos. 536-4 and 422-1, were normally sensitive to the feedback inhibition by lysine alone but altered so as to be insensitive to the feedback inhibition by threonine and that by lysine plus threonine. These properties of AKs were the same as those of the AK of the AEC plus threonine-resistant lysine producer derived from the wild strain of $B$. $f l a$ vum No. 2247. ${ }^{1)}$ Thus, in spite of the results of Tosaka et al., we obtained mutants for the purpose of this study, that is, with both feedbackresistant AKs and a PK defect. However, these mutants had acquired another character which was unfavorable for lysine production, i.e., resistance of HD to feedback inhibition by threonine. A HD of this type converts considerable amounts of aspartate- $\beta$-semialdehyde, a common intermediate for aspartate family amino acids biosynthesis, to threonine or isoleucine, resulting in a decrease in the lysine productivity. The above character, which was in common with AHV-resistant threonine or isoleucine producers, would naturally be expected from the selection method used for mutants, i.e., resistance to AHV plus lysine.

Next, to obtain $\mathrm{AK}^{\mathrm{R}}$ type lysine producers with a PK defect but without the above unfavorable character for lysine production, we tried to isolate $\mathrm{PK}$-defective mutants from $\mathrm{AK}^{\mathrm{R}}$ type strain No. 2-190. Since the parent strain No. 2-190 had resistance to AEC plus threonine, the conventional selection method, involving resistance to AEC plus threonine, was not applicable in this case to obtain PKdefective mutants. Thus, to solve the problem, some properties of the PK-defective strains so far obtained were studied. Among them, the inability to grow on ribose was confirmed as a possible selection marker for the isolation of mutants with a PK defect. The details were published in a separate paper. ${ }^{4)}$ The results described in this paper were the first application of this new method to the breeding of amino acid producers. All the three PK- 
defective mutants obtained produced more lysine than the parent strain, No. 2-190. In particular, strain KL-18 showed better productivity than that of the parent strain under all cultural conditions tested, with the maximum accumulation of $43 \mathrm{~g} / 1$ (yield, $43 \%$ ).

From these results, it will be concluded that the lysine productivities of $\mathrm{AK}^{\mathrm{R}}$ mutants can be improved by endowing them with a PK deficiency.

In addition to the above conclusion, through investigation of the cultural conditions, the lysine productivity of parent strain No. 2-190 was increased to $38 \mathrm{~g} / 1$ (yield, $38 \%$ ) in an industrially applicable medium. This yield was higher than that obtained with HD-defective lysine producer $\mathrm{H}-3-4$, derived from the same parent strain, No. $15-8 .^{2,3)}$

Acknowledgments. The authors are indebted to Dr. Y. Komachiya and Dr. R. Tsugawa of the Central Reserch
Laboratories for their encouragement during this work.

\section{REFERENCES}

1) I. Shiio, J. Ferment. Technol., 52, 62 (1974).

2) H. Ozaki and I. Shiio, Agric. Biol. Chem., 47, 1569 (1983).

3) I. Shiio, H. Ozaki and K. Ujigawa-Takeda, Agric. Biol. Chem., 46, 101 (1982).

4) M. Mori and I. Shiio, Agric. Biol. Chem., 51, 129 (1987).

5) I. Shiio and S. Nakamori, Agric. Biol. Chem., 34, 448 (1970).

6) I. Shiio, S. Sugimoto and Y. Toride, Agric. Biol. Chem., 48, 1551 (1984).

7) I. Shiio and K. Ujigawa, J. Biochem., 84, 647 (1978).

8) S. Black and N. Wright, J. Biol. Chem., 213, 39 (1955).

9) F. O. Chinard, J. Biol. Chem., 199, 91 (1952).

10) R. Miyajima and I. Shiio, J. Biochem., 68, 311 (1970).

11) I. Shiio and R. Miyajima, J. Biochem., 65, 894 (1969).

12) H. Ozaki and I. Shiio, J. Biochem., 66, 297 (1969).

13) O. Tosaka, K. Takinami and Y. Hirose, Agric. Biol. Chem., 42, 745 (1978). 